\title{
A Global Corporation
}

\section{A HISTORY OF THE INTERNATIONAL DEVELOP- MENT OF MASSEY-FERGUSON LIMITED}

The international or multi-national corporation has become an important phenomenon in today's business world and Massey Ferguson is an ideal example of such an organization. Through its predecessor companies it can trace its history to 1847 , and so it has encountered virtually all the difficulties and developments of the last hundred years in business organization and management science. The development has not been straightforward, for it has been much more than the growth of a single company in an expanding market. Management reorganization and the introduction of new management planning and control techniques contributed a good deal to the company's expansion, and because mergers played a vital role, the history of other companies is also involved.

Dr. Neufeld's study concentrates on the years after the Second World War, a period in which the company's international operations became increasingly complex. He records the events that helped to shape the company's character and structure, and at the same time investigates the company's successes and failures in adjusting to a changing national and international business environment. His study reveals why Massey-Ferguson developed into a global corporation, an organization that considers the whole of the international environment when making decisions relating to the allocation of its marketing, purchasing, manufacturing and engineering activities.

Dr. Neufeld skilfully combines historical description and analysis in this account, which is not only a biography of a company but also a chronicle of a whole era in the world of business and international development.

Born in Saskatchewan, E. P. Neufeld graduated in economics from the University of Saskatchewan in 1951 and received his $\mathrm{PhD}$ in 1954 from the London School of Economics. After two years with the Bank of England, Dr. Neufeld joined the Staff of the Department of Political Economy at the University of Toronto. He was appointed Professor of Economics in 1965 and is also Director of Graduate Studies in this department. 
E. P. NEUFELD

\section{A Global Corporation}

A HISTORY OF THE INTERNATIONAL DEVELOPMENT OF MASSEY-FERGUSON LIMITED 
(C) University of Toronto Press, 1969

Reprinted 2017

ISBN 978-0-8020-3204-1 (cloth)

ISBN 978-1-4875-8709-3 (paper) 
I dedicate this book to my wife 